\title{
About the usefulness and harmfulness of forgetting the German guilt
}

\author{
Paweł WÓJS*
}

\begin{abstract}
The distinction between kinds of guilt has not lost its power to illuminate matters, and it remains a great tool to study the consequences of forgetting guilt of any kind. Karl Jaspers made the distinction between kinds of guilt mainly to ease the Germans coping with guilt, as all of them were blamed for the evil that happened under Adolf Hitler. Jaspers believed that in using this distinction the German nation could have come back to its origins, and thus purified, take its part in the possible future unity of the world and of all mankind. But soon after World War II ended, a confluence of political, social, psychological and philosophical factors contributed to a situation in which a large number of culprits were not brought to account: criminals were rarely rightly punished. In addition, many Germans believing in the ideology of National Socialism felt no guilt in terms of morality; they downplayed the political guilt; they negated the very existence of the metaphysical guilt. The process of forgetting guilt occurred.
\end{abstract}

\section{KEYWORDS}

guilt; German guilt; forgetting guilt; memory; World War II; boundary situations; Karl Jaspers; Friedrich Nietzsche; Hannah Arendt

* Ph.D., assistant professor, Pedagogical University of Cracow, Department of Philosophy and Sociology. E-mail: pawel.wojs@up.krakow.pl. 


\section{INTRODUCTION}

The reality of Germans right after the end of World War II could be called an undifferentiated guilt. Jaspers wrote: "In the world today the German whoever the German may be - is regarded as something one would rather not have to do with" (Jaspers, 2000: 69). The case is that the whole German nation was regarded as guilty of the evil of World War II. The extent of evil was fully visible neither to Jaspers nor to any individual German, because since the very beginning it had been deliberately hidden. ${ }^{1}$ It took many years of research to successively reveal the scale of terror (including plans of eliminating whole nations as well as exterminating the people of culture, science, politics and church of conquered Poland); unimaginable cruelty on the scale never seen before (for example, the industrialization of killing people - gas chambers, turning human body parts into utilitarian objects, methodic removal of dead bodies of the ones killed in crematories); and destroying culture (for example burning down the libraries, cinemas, theaters in occupied Poland and mass stealing of art works). Figure 1 presents the scheme of this situation.

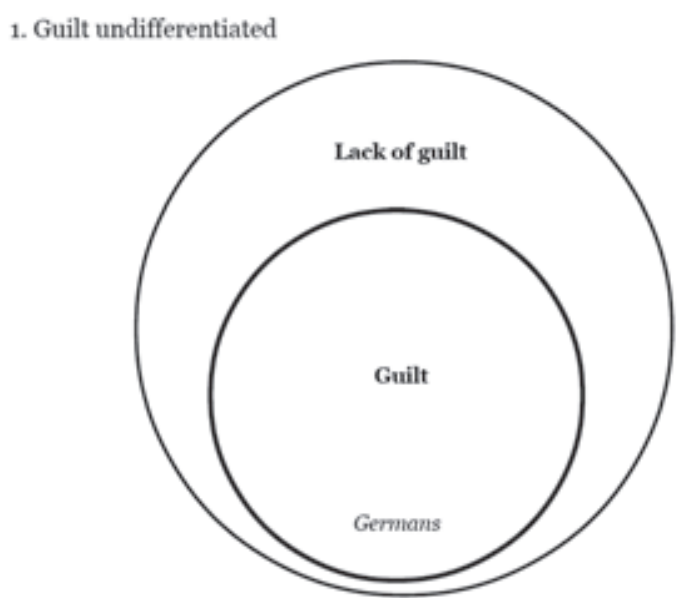

The famous differentiation of guilt presented by Jaspers in the book The question of German guilt (Die Schuldfrage) (Jaspers, 2000) is based on distinction of four kinds of guilt: criminal guilt, political guilt, moral guilt and metaphysical guilt. The philosopher made this distinction with the intention to show Germans a way to personal acceptance with dignity of the clearly recognized

${ }^{1}$ See Arendt, 2006: 257: "It is true that totalitarian domination tried to establish these holes of oblivion into which all deeds, good and evil [...]. The holes of oblivion do not exist. Nothing human is that perfect, and there are simply too many people in the world to make oblivion possible. One man will always be left alive to tell the story". 
guilt, but not to breaking free of its burden. He was also convinced that his work would help clear the German case after World War II and bring order into human matters. He considered it nonsense to blame the whole German nation for the crimes of war and to put moral blame on all the Germans. It is worth adding that Jaspers clearly emphasized a few times that it was not his intention to lessen German guilt by differentiating four kinds of guilt. He was also far from putting any shade of blame on other nations.

If the whole German nation is not guilty to the same extent, then who is guilty? In answering that ultimate question (it was asked by German citizens as well as by citizens of other countries) Jaspers hoped for a possible getting back to origins, which he expected to renew the German core.

Parsing guilt into different kinds didn't bring the expected outcome. Many Germans who were guilty did not take the challenge that could have enabled absolution after fulfilling an essential condition of compensation. The differentiation of guilt itself wasn't generally accepted. It was either ignored or taken instrumentally, and got deformed and partially (or even fully) blurred. This is an ongoing process. There is constant conflict between people trying to erase the German guilt and people wanting to prevent that erasure. This is a harmful process for both sides: for the Germans who can't make amendment due to it and for other nations, especially the ones that were most painfully hurt, and - as a result - for the Jaspers' project of future union of nations. Sabine Arnold's saying that the memory is under occupation seems on point. ${ }^{2}$

\section{GUILT DIFFERENTIATED}

After the World War II had ended, a concurrence of political, social, psychological and philosophical factors contributed to the situation where huge number of culprits were not brought to account: criminals were rarely rightly punished. It is worth mentioning that according to the Convention on the Non-Applicability of Statutory Limitations to War Crimes and Crimes Against Humanity taken by General Assembly of the United Nations (New York, November 26, 1968), war crimes and crimes against humanity do not expire. It is estimated that there were about five million people involved in criminal actions in Germany, out of which only about one of each thousand were punished. ${ }^{3}$

${ }^{2}$ Arnold used the term "occupied memory" to describe a repressive and manipulative control of a totalitarian country over the process of shaping memory, but the metaphor also shows the process happening in connection to German guilt, see Arnold, 1998: 18.

3 See Kosiński, 2015: 56-57: "It is estimated that about five million citizens of German Reich around 1940 were indirectly or directly engaged in proceeding Hitler's criminal plans. Meanwhile in the years 1945-2005 the prosecutors in Western Germany (an American, British and French occupation zone) started about 37,000 cases considering Nazi crimes... Only 
Knowledge about the criminal acts of totalitarian regimes and about war crimes is especially vulnerable to forgetting, and that's where a problem of remembering guilt comes from. Primo Levi was on point saying that the III Reich history is "a war against memory" (Levi, 1986; cited in: Lezina, 2015: 98), because planned extermination also included removing witnesses. ${ }^{4}$

According to Jaspers, political guilt, unlike criminal guilt, is about the whole society, because in today's countries all the citizens take political actions, such as voting or not. Jaspers concluded: "Everybody is co-responsible for the way he is governed. Jurisdiction rests with the power and the will of the victor, in both domestic and foreign politics. Success decides" (Jaspers, 2000: 25). Jaspers highlighted that it was a misfortune and a common guilt of Germans that they lost their freedom by surrendering to the brutal, despotic government. Jaspers wrote that, as a result of political guilt: "There is liability for political guilt, consequently reparation is necessary and further loss or restriction of political power and political rights (on the part of the guilty)" (Jaspers, 2000: 30). However, some Germans in 1945 didn't feel any political guilt. Why? Jaspers assumed that the reason for throwing away political guilt is the same as the reason of surrendering to the regime: lack of internal political freedom.

The mechanism of denying political guilt or forgetting about it seems to have a solid psychological explanation. People tend to build their identity by, for example, getting closer to the ones who are successful, to places and ideas connected to victories. On the other hand, they get distant to those who lost. It is clearly visible in the outcomes of the public opinion polls: after the results of voting are announced, a support for those who lost lessens and more people declare that they voted for the winning party then actually did. That is why it is hard to expect people to cherish the memories of having supported (by themselves or their significant others) an ideology which brought a disaster to the country. However, in Germany it had very serious outcomes: lack of repayment for the loss, forgetting guilt, and lack of consequences of being engaged into Nazi regime, including lack of limitations of political power and political rights. One of the reasons for it were some short-term, cold war objectives of the allies, which made denazification process real quick

in 4,964 cases ( $14 \%$ of preparatory procedures) ended up with starting trials. In those trials 16 accused were punished with the highest punishments (4 death sentences were executed), 166 - life imprisonment sentences, 6,297 — imprisonment sentences (82 - from 10 up to 20 years, 360 - from 5 up to 10 years, 862 - from 2 up to 5 years, 1,139 - from 1 to 2 years, 1,996 - from 6 months to 1 year, 1,858 - up to 6 months, 130 were fined, and 47 stayed unpunished".

${ }^{4}$ Anna Akhmatova was talking about Stalin's terror, but the same words can be used while talking about Hitler's regime: "the death are silent, the living are silent as the death: otherwise they risk becoming dead as well”, cited in: Lezina, 2015: 98. 
and giving jobs to the officials with Hitler past. Such attitude made, as the Polish historian Paweł Kosiński summarized: "the German society take it as a proof that the crimes had been atoned and the past brushed aside" (Kosiński, 2015: 56).

Moral guilt is an individual matter, which is experiencing depression, overwhelming or torture coming from self-observation, self-accusation, being disappointed with oneself and blaming oneself for the free and, as it turned out, wrong decisions. A judge of the moral guilt is one's own conscience and it is them to take the moral guilt for their actions. Of course, there can be some mitigating circumstances, such as feeling threatened or made to do something, however the evil done still remains evil, even if it was done under pressure and it doesn't make moral guilt disappear. Such circumstances should be examined individually each time. However, it is worth adding that lack of feeling guilty is not identical to the lack of guilt. To the same extend as a well-recognized guilt, an unconscious or forgotten guilt still weighs heavily on an individual. A state of not feeling guilty can at any time be disturbed by bad conscience. Max Scheler wrote: "Guilt is a 'bad' quality, which has permanently adhered to person oneself - the center of their acts - by bad behaviors. So it is a quality, not a feeling... Whether a person feels guilty or not - the guilt itself ever lasts" (Scheler, 1921: 39; cited in: Grabowski, 1996: 51).

Jaspers thinks that someone who was engaged into Nazism can be purified only through a really deep transformation:

Whoever took part in the race mania, whoever had delusions of a revival based on fraud, whoever winked at the crimes then already committed is not merely liable but must renew himself morally. Whether and how he can do it is up to him alone, and scarcely open to any outside scrutiny (Jaspers, 2000: 63).

However, against Jaspers' optimism, most of Germans defended themselves from transformation by successfully using self-deception about the Nazi reality they lived in. Arendt wrote:

But the practice of self-deception had become so common, almost a moral prerequisite for survival, that even now, eighteen years after the collapse of the Nazi regime, when most of the specific content of its lies has been forgotten, it is sometimes difficult not to believe that mendacity has become an integral part of the German national character (Arendt, 2006: 85).

It is impossible to show directly what metaphysical guilt is. It is constantly present, but it's impossible to present it in a concrete way, rather generally, as an infringement to "an absolute solidarity with a human being itself" (Jaspers, 2000: 83). This lapse of solidarity takes place when someone is an unwilling witness of unfairness and crime. Jaspers said that just risking 
one's life while trying to prevent it is not enough: "if I survive where the other is killed, I know from a voice within myself: I am guilty of being still alive" (Jaspers, 2000: 65).

So, not remembering metaphysical guilt keeps a man at a shallow level of self-knowledge, with an exuberant pride and haughtiness. Does it mean that the lack of noticing metaphysical guilt, such as moral guilt mentioned before, is a kind of spiritual blindness? Maybe, considering this issue from another side, one may say that the spiritual growth, becoming oneself, which is on Jaspers' mind, is based on widening the range of guilt which I felt: from the stage of awareness of one's political guilt, through the awareness of moral guilt up to metaphysical guilt.

Criminal, political, moral and metaphysical guilt are closely interlinked, which is why it is impossible to talk about their exclusiveness. For example, on moral shortcomings grows political guilt and crime, and life of an individual is historically determined by a specific political institution. This contexture means coexistence, but not mixing. If mixing appears, it causes, according to Jaspers, loss of clarity and it always leads to unfair consequences, sometimes beneficial, sometimes wrong ones (Jaspers, 2000 70).

Analysis of kinds of guilt of Germans presented by Jaspers is shown in the illustration number 2. The entire German nation that carries political guilt is pointed as a set collection (2). Specific groups of German citizens are, however, different when it comes to different kinds of guilt. The illustration thus depicts this group of Germans who were passively watching the social-nationalist government, but not committing any crimes (subset $2 \backslash 1$ ). This subset is divided into Germans who, besides bearing political guilt, also remember their moral guilt, subset $A$ : $(2 \cap 3) \backslash 1$, and those who don't remember their moral guilt subset $B: 2 \backslash(1 \cup 3)$.

Germans who carry both political and criminal guilt are another subset $(2 \cap 1)$. In the last group, one can distinguish Germans who besides political and criminal guilt also felt moral guilt - subset C: $(1 \cap 2 \cap 3)$ - and Germans who, being politically and criminally guilty, don't feel any moral guilt - subset D: $(2 \cap 1) \backslash 3$.

The illustration also presents Jaspers' conviction that the entire human race - not just Germans - carry metaphysical guilt (4).

Furthermore, the illustration shows a subset of non-Germans who carry moral guilt — subset M: $3 \backslash(1 \cup 2)$ - for example, for not standing up against authoritarian government in Germany, when the time came. There is also a subset of non-Germans who carry criminal guilt, with participation of those who feel morally guilty - subset N: $(3 \cap 1) \backslash 2$ - and those who don't - subset $\mathrm{O}: 1 \backslash(2 \cup 3)$. This group, e.g. the Waffen-SS volunteers, was not mentioned by Jaspers. 


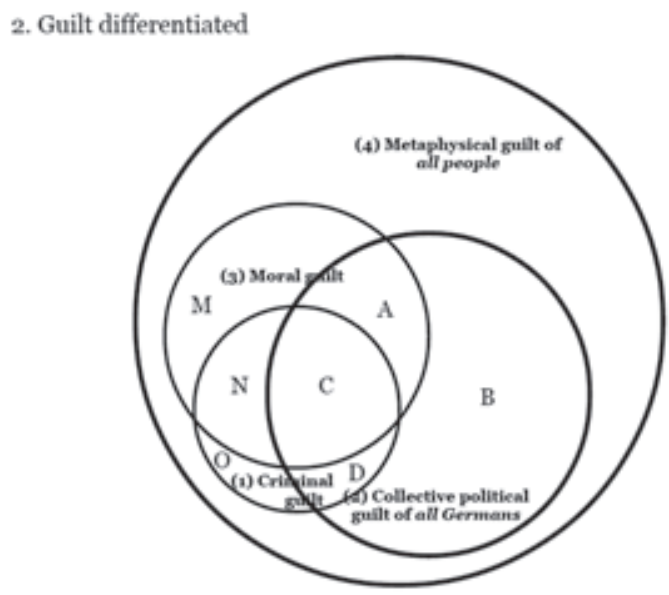

\section{FORGETTING GUILT}

Jaspers considered it his obligation to deeply explain the German guilt. He wrote: “This is our own business" (Jaspers, 2000: 43). Unfortunately, Jaspers' academic style used in trying to convince his fellow Germans to accept their faults and the will of victors didn't meet with common response. The philosopher even noticed a strong tendency to avoid problem of guilt. Some Germans not only didn't mean to do anything to explain problem of guilt, but they didn't even want to hear anything about it. Others either accepted guilt or, being convinced of their own innocence, attributed guilt to others (Jaspers, 2000: 21).

Jaspers noticed the possibility to sophistically push away guilt in general through using his differentiation of guilt to give oneself absolution, to avoid accusation, to push guilt away, or to make it be forgotten. These ways considering four kinds of guilt can be described as follows:

1. Criminal guilt: "it does not concern me" (Jaspers, 2000: 68).

2. Political liability: "it curtails only my material possibilities; I myself, my inner self is not affected by that at all" (Jaspers, 2000: 68).

3. Moral guilt: "my conscience is not going to be too hard on me. It wasn't really so bad; let's forget about it, and make a fresh start" (Jaspers, 2000: 68).

4. Metaphysical guilt: "That's a crazy idea of some philosopher. There is no such thing. And if there were, I wouldn't notice it. That I needn't bother with" (Jaspers, 2000: 68).

Each of these excuses leads to denying guilt, to not remembering it.

Jaspers distinguished between being grumpy and being proudly stubborn as two characteristics of the blamed person, meaning closing within oneself and accepting in different ways of what was wrong, lacking any will for atonement, 
which drags another victim in. In addition, the philosopher notes that being grumpy has a tendency to turn into compulsively confessing one's guilt, which is connected to a desire of power and pleasure. In this case:

Such confessions of guilt - false, because still instinctive and lustful - have one unmistakable external trait: fed by the same will to power as their opposites in the same individual, they betray the confessor's wish to enhance his worth by his confession, to eclipse others (Jaspers, 2000: 101).

You might add that such confession of guilt is not authentic, which is completely different - it is combined with feeling an unbearable weight, which accompanies feeling guilty, and also with regret, desire to gain absolution from the hurt ones, and with an active pursuit of expiation.

The philosopher also showed that where there is no awareness of guilt, pointing at it is often considered an attack and meets a symmetrical answer. In other words, realizing guilt which someone was able to suppress brings anger.

While encouraging people to accept guilt, Jaspers wrote that a person who accepted guilt can bear false and unjust accusations with tranquility (see Jaspers, 2000: 115). These convictions made sense until someone started to forcefully negate the division between perpetrators and victims. Jaspers could not have foreseen that within a few decades, there would be a need to defend honor of the victims exterminated by Germans, who are falsely accused of participation in crimes.

Social opinion polls show that in 1946, the Nuremberg trials had just come to an end, and most of Germans considered it as "Fair, eye-opening and necessary, and judgments moderate" (Kosiński, 2015: 58). Half of the interviewees agreed to accept partial responsibility for the outcomes of Hitler's dictatorship and the other half claimed it was enough to punish the leaders. After the subsequent trials ended, at the beginning of 1950s, it was only one-third of the interviewed Germans who thought that the Nuremberg trials were fair. Almost the same number of Germans assumed the judgments were too severe.

Kosiński, who was researching polls on Nuremberg trials, didn't definitely establish what caused such a quick change. The reason might have been a previous practice of concealing reserve towards the allies' actions, caused by the fear of more severe denazification. Additional reasons might include a chain of allies' sanctions and further trials mentioned in the poll, or a protest against common guilt while feeling personally responsible for the crime, or an unconscious call to put an end to clearing the past while facing the soviet threat. It is definitely considered a mistake to "lump together Hitler's massive crimes and war crimes, which made public opinion indifferent" (Kosiński, 2015: 59). Moreover, as a result of defeat, level of destruction of the country, poverty and denazification process, Germans began to perceive themselves as victims. 
Feelings of victimhood were even reinforced in Germans by politicians who were discriminated against by the Nazi government. For example, Theodor Stelzer (CDU), as Kosiński reports, concluded in November 1945 that "basically the whole nation should be accounted as victims of Hitler's regime" analogically, Max Brauer (SPD) in less than four years after the war "called 'the whole nation' a victim of Hitler and his 'demonic methods". Paul Löbes (SPD) was no different: "twofold oppression German nation, suffering both "under their own tyranny's shoe' as well as in a result of allies war actions against Germany" (Kosiński, 2015: 62).

Even Jaspers himself called his motherland a Nazi prison, considering it an extenuation, in addition to its geographical location, historical situation in the world, and the faults of others. Nevertheless, one has to admit that Jaspers firmly stated that the German guilt is not lessened by those circumstances to any extent. He wrote: "A general truth must not serve to level out the particular, present truth of our own guilt" (Jaspers, 2000: 91). It is also worth mentioning that he didn't undertake research on guilt in the context of German aggression to the nearest countries and sufferings of other nations and his conclusion that Germans were also the "victims" of national socialism supporters, even against his intentions of ever spreading among Germans the tendency to forget guilt.

\section{NIETZSCHE ON MEMORY AND HISTORICAL SCIENCE}

There is insufficient space to gather together all the reasons which individually or collectively cause the phenomenon of forgetting guilt, which is why it is worthwhile to present a special reason, the philosophical one - ideas by Friedrich Nietzsche, a philosopher with probably the strongest influence, to whom also Jaspers often relates.

Nietzsche was proving that a man (unlike animals, which live only in the present) buckles under a weight of the past. That is why he considers forgetting, understood as the transformation of drive, as something beneficial. In the same spirit, he also expressed it in a dissertation entitled 'Guilt', 'bad conscience', and related matters:

Forgetfulness is not just a vis inertiae, as superficial people believe, but is rather an active ability to suppress, positive in the strongest sense of the word, to which we owe the fact that what we simply live through, experience, take in, no more enters our consciousness during digestion (one could call it spiritual ingestion) than does the thousand-fold process which takes place with our physical consumption of food, our so-called ingestion (Nietzsche, 2007: 35).

The ability to forget, according to Nietzsche, is not only a process of corroding the content of memory, but also a strong, positive, active mechanism 
serving life and contracting the ability to remember. It seems that the most famous expression of this opinion Nietzsche expressed in a sentence from $\mathrm{Be}$ yond good and evil: "I did that,' says my memory. 'I could not have done that,' says my pride, and remains inexorable. Eventually - the memory yields" (Nietzsche, 2002: 59).

In Nietzsche's On the use and abuse of bistory for life there are two sentences meaningful for Jaspers' analysis of guilt. In those sentences are names of Jaspers' boundary situations standing close to each other - with a significant lack of the boundary situation "guilt" (Scbuld). In the first sentence "a fight" (Kampf), "suffering" (Leiden), and (presented by Jaspers, but not as a boundary situation) "excess" (Überdruß), which while being experienced by a person who carries the weight of memory make them assured that their very existence is a kind of being that will never come to an end. In the other sentence, the word "death" is used. It is understood as an ultimate end of everything - the past, present and future. Nietzsche wrote:

For he learns to understand the expression "It was", that password with which struggle, suffering, and weariness come over human beings, so as to remind him what his existence basically is - a never completed past tense. If death finally brings the longed for forgetting, it nevertheless thereby destroys present existence and thus impresses its seal on the knowledge that existence is only an uninterrupted living in the past, something which exists for the purpose of self-denial, self-destruction, and self-contradiction (Nietzsche, 1998: 3).

Nietzsche believes destroying is a function of existence because according to him, a human lives by negating of what has been, and each action needs forgetting. So, the ability to forget in this interpretation has a liberating character; on the other hand, not remembering is the only acceptable way of a happy existence, and a man can feel innocent. Nietzsche's thesis is: "There is a degree of insomnia, of rumination, of the historical sense, through which living comes to harm and finally is destroyed, whether it is a person or a people or a culture" (Nietzsche, 1998: 4).

It is visible that Nietzsche was clearly against remembering "how it was". He was leaning towards an opinion that it is a right thing to use history instrumentally (even to some extend by making it up) to serve the current moment, to serve an instant good conscience. One might say that now Nietzsche would have been a fierce advocate of what he would have called, "a German dream" and "putting the world to sleep". Nietzsche's arbitrary perspective considers nothing but benefits of a perpetrator, either as an individual or a community, without reflecting on the memory of victims.

However, Jaspers cherished a category of fairness considering memory (which Nietzsche ridiculed). That is why, in the name of historic truth, 
he wanted to preserve truth about his nation's acts, without replacing it with a myth. It seems that Jaspers wouldn't have denied a voice, repeated in Poland, which is clearly non-Nietzschean. Józef Piłsudski said: "A nation that loses memory is no longer a nation - it is only a group of people who temporarily occupy some territory" (Piłsudski, 2018: 41). This thought was also expressed by Stefan Wyszyński: "A nation without history soon becomes a nation without land, a homeless nation, a futureless nation. A nation that doesn't believe in greatness and doesn't want great people extinguishes" (Wyszyński, 1979: 145).

\section{RUINING THE DISTINCTION OF FOUR KINDS OF GUILT}

Even before the start of Eichmann's trial (1961), Jaspers said in Der Monat that the Jerusalem court should resign from judging that case, because a court representing the whole human race should make judgments in this case. ${ }^{5}$ Arendt later added that this trial was about exterminating all ethnical groups by Germans - Jews, Poles, Gypsies - so there hadn't been enough effort to raise the trial to the proper global level, to show that the crime was against all human race. ${ }^{6}$ So, already in those times, when the scale of evil had been revealed, the weight of German guilt wasn't shown to the world. This guilt, which was only getting started to shape in a collective memory of humankind, was lessened from the very beginning. ${ }^{7}$

A conclusion by Martin Buber can serve as an example of blurring (or lack of knowledge of) differentiation introduced by Jaspers and of consequences it brings. After Buber found out about execution of Eichmann, he called it “'a mistake of historical dimensions,' as it might 'serve to expiate the guilt felt by many young persons in Germany"' (Arendt, 2006: 274). This argument sounds similar to Eichmann's statement, explaining why he hadn't tried to hide after noticing that he had been searched for by Israeli secret service, who later kidnapped him in Argentina. Eichmann claimed that he was under a strong impression of the news that German youths felt guilty:

${ }^{5}$ Further reflections on actions which contributed to collective memory loss about adequate awareness of German guilt were gathered for example by Novick, 1999.

${ }^{6}$ See Arendt, 2006: 296: "At no point, however, either in the proceedings or in the judgment, did the Jerusalem trial ever mention even the possibility that extermination of whole ethnic groups - the Jews, or the Poles, or the Gypsies - might be more than a crime against the Jewish or the Polish or the Gypsy people that the international order, and mankind in its entirety, might have been grievously hurt and endangered".

7 Assmann was on point writing that individuals do have memory, but only the ones shaped by a community, which is why one can metaphorically talk about collective memory. See Assmann, 2009: 66. 
This is also why I offered, in a written statement, at the beginning of this examination [...] to hang myself in public. I wanted to do my part in lifting the burden of guilt from German youth, for these young people are, after all, innocent of the events, and of the acts of their fathers, during the last war (Arendt, 2006: 266).

It seems that Buber's statement presents a lack of proper understanding of guilt, internal fight, or inability to fathom the range of guilt incomparable to any guilt ever known before. This thus leads to mixing criminal, moral, and political guilt and finding some non-existent connections between them, which might even be considered as an attempt to melt them into one general guilt.

A scheme of this problem is shown in the illustration number 3. It presents differentiation of guilt, but also a tendency to lose understanding of the meaning of this differentiation and mixing different kinds of guilt. There is a lack of awareness of metaphysical guilt (which is an ontological base for the other ones), and the other kinds are "leaking", which causes a state of mixing. After all, it is only the criminals who are responsible for crimes, so it would be unfair to blame all the citizens. Moral guilt is a matter of individual conscience, so it can't be imposed on anyone. Analogically, a fair punishment of a perpetrator doesn't eliminate political responsibility and moral guilt which concerns others. Similarly, taking consequences for political actions doesn't bring clean conscience.

Tangling different kinds of guilt, up to the level of undifferentiated guilt, could lead to the accusation of the German nation as a whole. There is also an opposite direction of taking the burden of any guilt off the German nation or at least some part of guilt, with an ever-progressing process of blaming the innocents.

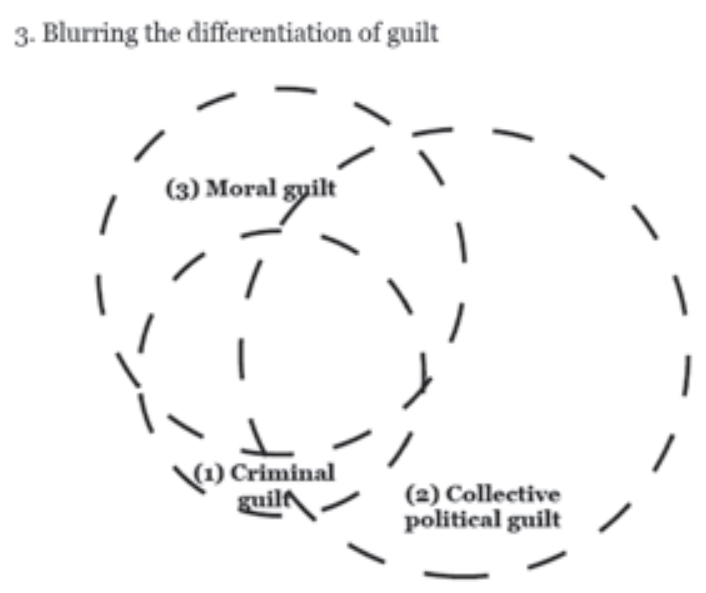


Another kind of deformation of guilt differentiation, which also omits metaphysical guilt, can be called a tendency to distill each kind of guilt or a process of polarization of groups characterized by different kinds of guilt. In this process, the members of one's own group are juxtaposed with the members of the opposite group according to the rule "us and them", "us the Germans them the Nazis", "us the victims - them the perpetrators". An effect of such a process is presented in the illustration 4. It shows the effect of divergence of national and political party membership, which made it even easier for Germans to find themselves among victims and using a term "Nazi extermination camps" or "Nazi crimes" without pointing at Germany, which is the only country responsible for them.

The illustration also shows that among the morally guilty people, without pointing to nationality, there are also witnesses listed, meaning the people who survived extermination being victims. Exposing the presence of those people among those morally guilty reveals a tendency contradictory to Jaspers' thesis of attributing moral guilt to someone else while it can be only recognized as one's own, not by someone else's pointing. It may be called an excessively ordered guilt. A psychological mechanism which might explain a tendency to attribute guilt also to victims is a cognitive distortion called a belief in just-world. An example can be the anti-polonism explained by the following sophism: "In comparison to Jews, the percentage of Poles who survived World War II is higher, so the Poles are complicit of Jewish extermination”. It is worth adding that this kind of slanderous conclusion sometimes completely omits the Germans with the whole context of those events.

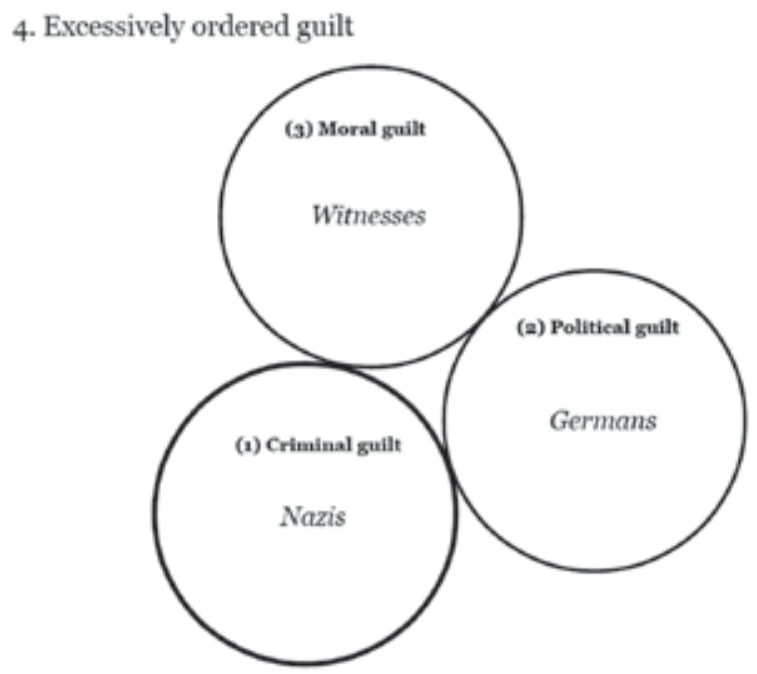


The third kind of deformation of guilt differentiation is based on both of the above-mentioned tendencies: blurring the difference between kinds of guilt with a simultaneous distillation of them. A fifth type of guilt can be created by placing all of Jaspers' types of guilt into an artificial and specious order:

1. criminally guilty people, who are at the same time politically, morally and metaphysically guilty;

2. politically guilty people, who are also morally and metaphysically guilty, but not criminally guilty;

3. morally and metaphysically guilty people, without political or criminal guilt;

4. only metaphysically guilty;

5. innocents (a category of people perceived by some as people who do not carry any guilt, which is a negation of Jaspers' concept).

There is no distinct demarcation between these types. The unsealing of each type of guilt allows mixing, which can be harmful to some and beneficial to others. An arbitrary progressing centrifugal movement, which can be called erasing guilt, is accompanied by a centripetal one, which can be called attributing guilt.

This deformation process is supported by lack of knowledge about war reality. Krystyna T. Zamorska formulated this thought accurately as an "Americanized" way of writing about World War II, which omits the problem of war against Poland and Poles: "First of all without genocidal German occupation, Poles are no longer victims and become spectators of the Holocaust" (Zamorska, 2015: 303). A further consequence of this process was a common supposition that Poles could have done more to defend the Jews against Germans and some accidents of attributing death camps basing on geography instead of the contemporary German jurisdiction.

So, it becomes visible that the consequence of losing memory about Jaspers' types of guilt in a progressive lessening of German guilt up to the level of forgetting it or removing it to other nations according to the following false logics. After all, there are examples of innocent German heroes, such as the Scholls, so it can't be stated that "all German are guilty". Further, there are individuals other than Germans, who participated in acts of crime, so one can't say: "everyone but Germans is innocent". In other words, it only takes one evil individual to negate the sense of existence of a group of morally innocent victims. Pure sophism. There also come false generalizations and lies, such as calling some victims, for example Poles, Hitler's co-workers. ${ }^{8}$

${ }^{8}$ Nazi Germany's chief jurist in the occupied Poland “General Government” territory, Hans Frank wrote in his diary (January 12, 1944): "When we finally win the war, then when it comes to me, meat carcasses can be made out of Poles, Ukrainians and others fooling around. Let it be, what is to be. But currently we need to keep in order, calm, work and discipline 15 million 


\section{Confusing culprits with the victims}

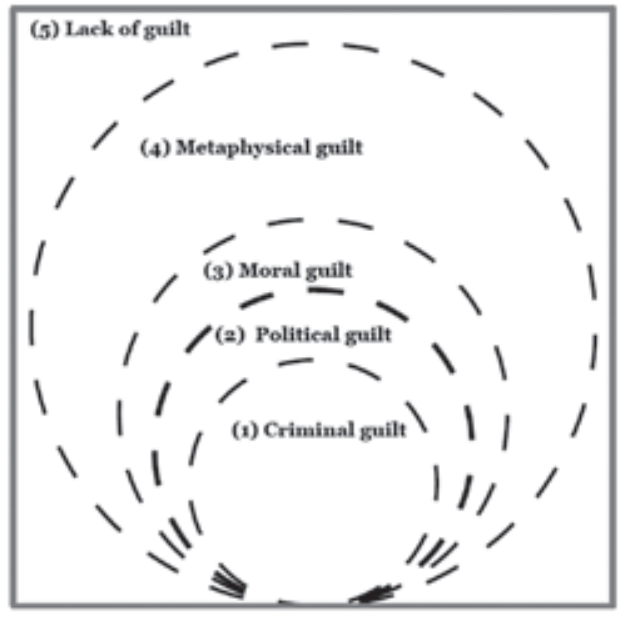

\section{CURRENT CONDITIONS}

In a February 2018 report from the phone poll made by Foundation Remembrance, Responsibility and Future ${ }^{9}$ and Bielefeld University on a group of 1,016 people aged 16 to 92 years, one can read that $54.4 \%$ of Germans consider themselves as victims (!) of Hitler's politics and only $17.7 \%$ of Germans admit that there were perpetrators of Nazi crimes among their ancestors. A total of $55.7 \%$ of the interviewees definitely negate their guilt of extermination of Jews; 20.5\% "rather" negate it. The statement: "I feel guilty of Holocaust, although I haven't done anything wrong myself" was definitely supported by $4.5 \%$ of interviewed Germans; $5.9 \%$ accepted this opinion ${ }^{10}$.

\section{CONCLUSION}

Jaspers, disappointed with the slim understanding of the moral dimension of guilt of the German people, seeing sparkling careers of many Nazis in West Germany structures, demonstrated his disapproval by leaving his motherland

of a hostile nation, which organizes itself against us. If it won't work, I will at least be able to victoriously say I killed 2 million Polacken” (cited by Batawia, 1951: 18).

${ }^{9}$ EVZ (Erinnerung, Verantwortung und Zukunft).

${ }^{10}$ See "Study examines Germans' relationship with Nazi past". In: Deutsche Welle, https:// www.dw.com/en/study-examines-germans-relationship-with-nazi-past/a-42572242 (accessed 4.10.2019). 
in 1948 and later renouncing German citizenship in 1967. Nevertheless, he remained a guardian of a German conscience and memory:

A crime is atoned for; a political liability is limited by a peace treaty and thus brought to an end. As far as these two points are concerned, the idea is correct and meaningful. But moral and metaphysical guilt, which are understood only by the individual in his community, are by their very nature not atoned for. They do not cease. Whoever bears them enters upon a process lasting all his life (Jaspers, 2000: 111).

\section{BIBLIOGRAPHY}

Arendt, H. (2006). Eichmann in Jerusalem. A report on the banality of evil. (A. Elon, Introd.). New York: Penguin Book.

Arnold, S. (1998). Stalingrad im Sowjetischen Gedäcbtnis. Kriegserinnerung und Gescbichtsbild im totalitären Staat. Bochun: Projekt Verlag.

Assmann, J. (2009). Kultura pamięci.(pp. 59-99). In: M. Saryusz-Wolska (Ed.). Pamięć zbiorowa $i$ kulturowa. Wspótczesna perspektywa niemiecka. Kraków: Universitas.

Batawia, S. (1951). Rudolf Hoess. Komendant Obozu Koncentracyjnego w Oświęcimiu (pp. 9-58). In: Biuletyn Gtównej Komisji Badania Zbrodni Hitlerowskich w Polsce (vol. 7). Warszawa: Wydawnictwo Ministerstwa Sprawiedliwości.

Fürstenau M. (2018). Study examines Germans' relationship with Nazi past. Retrieved from: https://www.dw.com/en/study-examines-germans-relationship-with-nazi-past/a-425 $72242(04.10 .2019)$.

Grabowski, M. (1996). Ku realności winy. Etyka, 29, 47-55.

Jaspers, K. (1993). Autobiografia filozoficzna. (S. Tyrowicz, Trans.). Toruń: Wydawnictwo Comer.

Jaspers, K. (1978). Sytuacje graniczne (pp. 186-242). In: R. Rudziński. Jaspers. Warszawa: Wiedza Powszechna.

Jaspers, K. (2000). The question of German guilt. (J.W. Koterski, Introd.; E.B. Ashton, Trans.). New York: Fordham University Press.

Kosiński, P. (2015). Recepcja procesów norymberskich w zachodnich strefach okupacyjnych, RFN i zjednoczonych Niemczech (pp. 48-73). In: P. Pleskot (Ed.). Wina i kara. Spoteczeństwa wobec rozliczeń zbrodni popetnionych przez reżimy totalitarne w latach 19391956. Warszawa: Instytut Pamięci Narodowej.

Levi, P. (1986). I sommersi e i salvati. Torino: Einaudi.

Lezina, J. (2015). Rozliczanie przeszłości nazistowskiej w Niemczech Zachodnich: źródła ciągłości i zmiany w powojennej pamięci zbiorowej (pp. 97-128). In: P. Pleskot (Ed.). Wina $i$ kara. Społeczeństwa wobec rozliczeń zbrodni popetnionych przez reżimy totalitarne $w$ latach 1939-1956. Warszawa: Instytut Pamięci Narodowej.

Nietzsche, F. (1998). On the use and abuse of history for life. (I.C. Johnston, Trans.), Nanaimo: Vancouver Island University.

Nietzsche, F. (2002). Beyond good and evil. (J. Norman, Trans.). New York: Cambridge University Press.

Nietzsche, F. (2007). 'Guilt', 'bad conscience', and related matters. In: F. Nietzsche. On the genealogy of morality. (C. Diethe, Trans.). New York: Cambridge University Press.

Novick, P. (1999). Holocaust in American life. Boston: Houghton Mifflin Company.

Piłsudski J. (2018). Myśli i wypsknięcia. Warszawa: Wydawnictwo MG. 
Scheler, M. (1921). Reue und Wiedergeburt in Vom Ewigen im Menschen. Leipzig: Verlag Der Neue Geist.

Snyder, T. (2010). Bloodland. Europe between Hitler and Stalin. New York: Basic Books.

Wyszyński, S. (1979). Z rozważań nad kultura ojczystą. Poznań-Warszawa: Wydawnictwo Pallottinum.

Zamorska, K. (2015). II wojna światowa i zimna wojna. Powojenna amerykanizacja niemieckich zbrodni popetnionych w Polsce (pp. 293-308). In: P. Pleskot (Ed.). Wina i kara. Społeczeństwa wobec rozliczeń zbrodni popetnionych przez rezimy totalitarne w latach 1939-1956. Warszawa: Instytut Pamięci Narodowej. 
